(i)

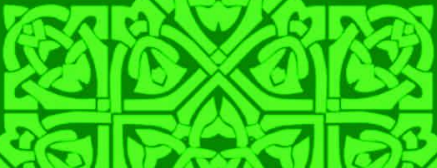

$4(5)$ a

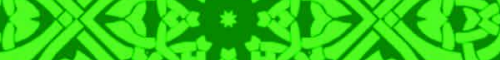

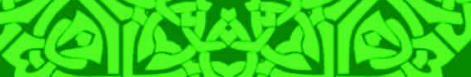

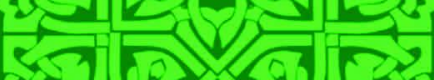

(i)

सहा

400

(a)

(4)

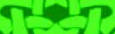

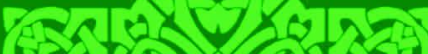

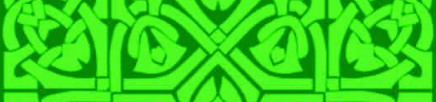

2

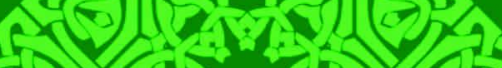

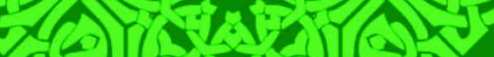

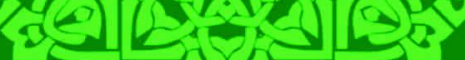

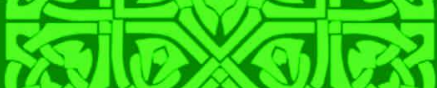

Gel

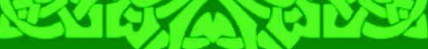

40

$\checkmark$

(क)

20?

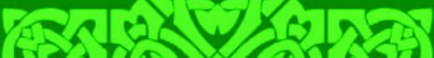

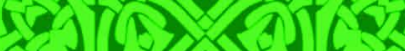

$+2$

tर
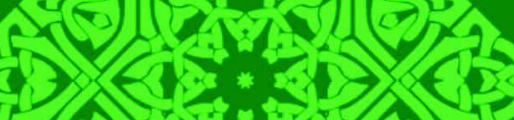

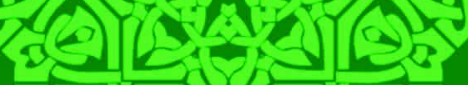

रत्र कि 02

cas as

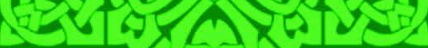

60

w

Vol 19. No $1 / 2019$
Rabiatul Adawiah, Srimusdikawati Contextualization And Entextualization Mandarese Patriotism In Kalindaqdaq Pettomuaneang Performance

Mahmuddin دراسة لغوية عن المجاز و علاقته في فهم التعاليم الدينية

Andi Miswar

Semantic Analysis On The Use Of Hijab And Jilbab Based On Quran Perspective

Aksa Muhammad Nawawi أغر اض الاستفهام بـ "هل" فى الذكر الحكيم

Syamzan Syukur Endogamy Marriage Tradition Of Sayyid Community In Sidenre Village, Binamu District, Jeneponto Regency 


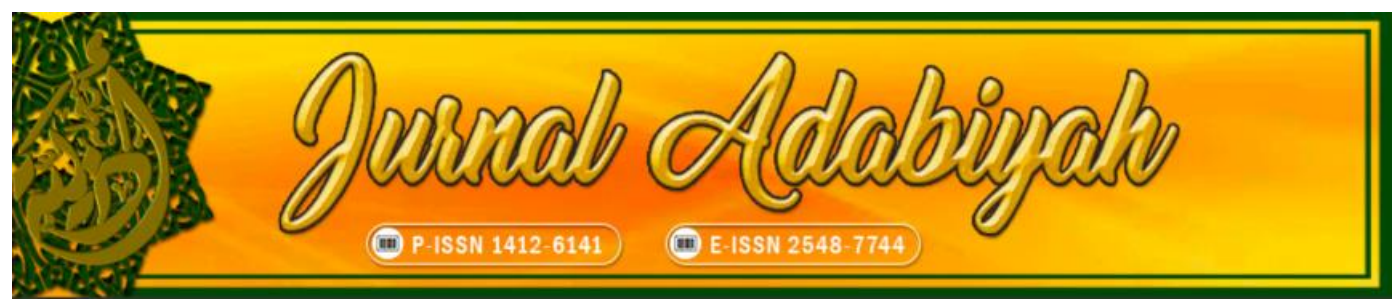

Thema: Humanities

\section{VOLUME 19 NO. 1 JUNI 2019}

\section{EDITOR-IN-CHIEF}

Barsihannor, Alauddin State Islamic University, Indonesia

INTERNATIONAL EDITORIAL BOARD

Nuri Emmiyati, Alauddin State Islamic University, Indonesia

Minako Sakai, Australian National University (ANU), Australia

Abd Rauf Muhammad Amin, Fakulti Syariah Kupu SB Brunei Darussalam, Brunei Darussalam Muhammad Widus Sempo, Universiti Sains Islam Malaysia, Malaysia

Salih Yousif Sharaf Mohamed, Al-Gazera University, Sudan Aishah Waenaha Waemamah, Academy of Islamic and Arabic Studies Princess of Naradhiwas University - Thailand, Thailand

\section{EXECUTIVE EDITOR}

Umar Thamrin, Universitas Islam Negeri Alauddin, Indonesia

\section{MANAGING EDITOR}

Zaenal Abidin, Universitas Islam Negeri Alauddin

\section{EDITORS}

Rosmah Tami, Alauddin State Islamic University, Indonesia Haniah Haniah, Alauddin State Islamic University, Indonesia Nasrum Nasrum, Alauddin State Islamic University, Indonesia Awaluddin Syamsu, Universitas Muslim Indonesia

Ahmadi Usman, UIN Syarif Hidayatullah Jakarta, Indonesia Baso Pallawagau, IAIN Parepare, Indonesia Muhammad Azwar, Universitas Islam Negeri Syarif Hidayatullah Jakarta, Indonesia

Muh. Saleh Syamsuri, Alauddin State Islamic University, Indonesia

Andi Satrianingsih, Muhammadiyah University, Indonesia

Syahruni - Junaid, Alauddin State Islamic University, Indonesia

Rabiatul Adawiah, Majene Islamic State College, West Sulawesi, Indonesia, Indonesia

Chusnul Chatimah Asmad, Universitas Islam Negeri Alauddin, Indonesia

Nur Arifin, Universitas Islam Negeri Alauddin, Indonesia

\section{IT SUPPORT}

Taufiq Mathar, Alauddin State Islamic University, Indonesia

\section{LANGUAGE ADVISOR}

Kustiwan Syarief, Alauddin State Islamic University, Indonesia Muh. Saleh Syamsuri, Alauddin State Islamic University, Indonesia

\section{COVER DESIGNER}

Nur Arifin 


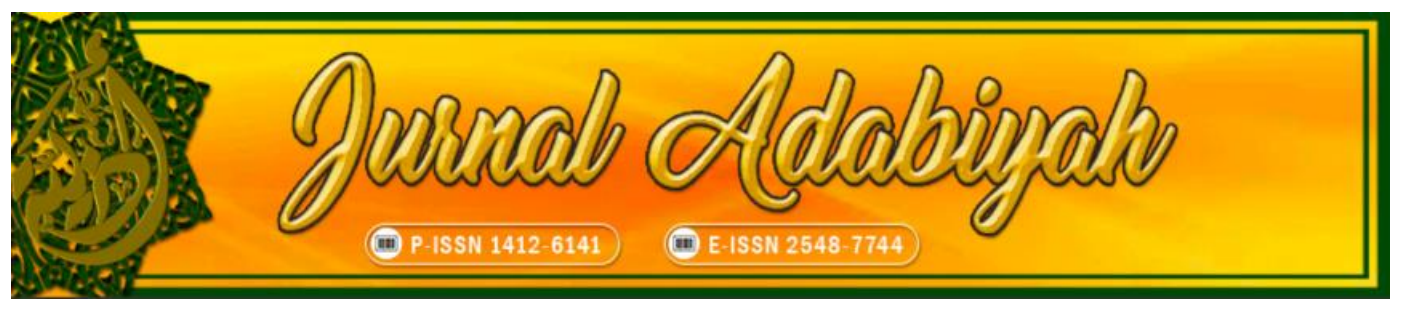

\section{Jurnal Adabiyah:}

This journal receives a national accreditation from Ministry of Research, Technology, and Higher Education Republic of Indonesia, Nomor 10/E/KPT/2019 on April 4, 2019 with the SINTA score: S2.

The Journal has been published by the Faculty of Adab and Humanity of Alauddin State Islamic University, Makassar, since 1997 and has been online since 2016 with the main themes on Humanities and Islamic Studies with the emphasis on interdisciplinary and intertextuality approach.

This journal are published twice a year, on June and December. The themes related to Islamic Studies are textual studies, scriptural traditions, Islamic law, and theology; and those related to Humanities are language, literature, history, and culture.

The journal of Humanities and Islamic Studies will provide the online collection of articles from 1997 up to now. The most updated information can be found on the website. 


\section{Table of Contents}

Rabiatul Adawiah, Srimusdikawati

Contextualization And Entextualization Mandarese Patriotism In

Kalindaqdaq Pettomuaneang Performance

Mahmuddin

در اسة لغوية عن المجاز و علاقته في فهم التعاليم الدينية

Andi Miswar

Semantic Analysis On The Use Of Hijab And Jilbab Based On Qur'an Perspective

Aksa Muhammad Nawawi

أغر اض الاستفهام بـ "هل" فى الذكر الحكيم

Syamzan Syukur, Arbianti

86-102

Endogamy Marriage Tradition Of Sayyid Community In Sidenre Village,

Binamu District, Jeneponto Regency 


\title{
ENDOGAMY MARRIAGE TRADITION OF SAYYID COMMUNITY IN SIDENRE VILLAGE, BINAMU DISTRICT, JENEPONTO REGENCY
}

\author{
Syamzan Syukur \\ Universitas Islam Negeri Alauddin Makassar \\ zansyukur@yahoo.com \\ Arbianti \\ Fakultas Adab dan Humaniora UIN Alauddin Makassar
}

\begin{abstract}
This article tried to find out some questions below, first, the way of marital processions of endogamy marriage at Binamu District of Jeneponto District. Secondly, the social impact of endogamy marriage. Thirdly, what is the sanction of disobeying the rules of endogamy marriage. This research was qualitative descriptive which means to explore the phenomenon of endogamy marriage at Binamu of Jeneponto District This article was actually tried to reveal whether or not Sayyed community in the Sidenre Subdistrict still maintained the tradition of edogamy marriage (The marriage between clans or kinship among them). Sayye' women were named as syarifah or sayyidah who were prohibited marrying with men who were not Sayye', because they cannot continue their clan. Whereas men are not given clan or kinship restrictions in conducting marital relations (patriarchal system). Sayyid community maintained this tradition as an attempt to maintain their clan which they believe that they had lineage from the Prophet Muhammad Saw. This tradition is certainly faced many problems among mellinea society. Nevertheless, this tradition still existed among Sayye community. The marriage of this tradition is impact to the limitation in choosing marriage partner which effected many syarifah or sayyidah became spinster, it also showed that there are some prohibition and limitation of interacting to other people, especially in establishing interpersonal with other clans. The sanctions for those who do not obey this tradition are isolated from community or broke down the cognation genetic relationships.
\end{abstract}

Keywords: Tradition, Marriage, Endogamy, Sayyid Community.

\begin{abstract}
Abstrak
Tulisan ini menjawab pertanyaan, Pertama, bagaimana prosesi tradisi pernikahan endogamy masyarakat sayye di Kelurahan Sidenre Kecamatan Binamu Kabupaten Jeneponto. Kedua, bagaimana dampak
\end{abstract}


sosial tradisi pernikahan endogamy masyarakat sayye, Ketiga, apa sanksi bagi yang melanggar tradisi pernikahan endogamy masyarakat sayye'. Penelitian ini adalah penelitian deskriptif-kualitatif, yakni penelitian yang dimaksudkan untuk memahami fenomena atau peristiwa mengenai tradisi perkawinan endagamy pada masyarakat sayye di Binamu Temuan tulisan ini menunjukkan bahwa masyarakat sayye' di kelurahan Sidenre Kecamatan Binamu Kabupaten Jenneponto mempertahankan tradisi perkawinan edogami (perkawinan antar klan atau kekerabatan dalam lingkup yang sama). Perempuan-perempuan sayye' yang biasa disebut syarifah atau sayyidah tidak diperkenankan kawin dengan lakilaki yang bukan sayye', karena perempuan dianggap tidak akan melanjutkan klan mereka. Sedangkan laki-laki tidak diberikan batasan klan atau kekerabatan dalam melakukan hubungan perkawinan (sistem patriarki). Masyarakat sayye' mempertahankan tradisi ini sebagai usaha mempertahankan klan mereka yang mereka yakini merupakan keturunan Rasulullah SAW. Tradisi ini tentu tidak mudah, apa lagi dalam konteks masyarakat mellinea. Kendati demikian, tradisi ini tetap hidup dalam masyarakat sayye' sampai sekarang. Dampak dari tradisi perkawinan ini adalah pertama, Adanya batasan dalam memilih jodoh sehingga banyak syarifah atau sayyidah menjadi perwan tua, kedua, nampak adanya tekanan atau pembatasan dalam berinteraksi, khususnya dalam menjalin hubungan dengan klan yang lain. Adapun sanksi bagi yang tidak mematuhi tradisi ini adalah berupa pengasingan dari keluarga dan masyarakat sayye atau memutuskan hubungan darah dan kekerabatan.

Kata Kunci: Tradisi, Perkawinan, Endogamy, Mayarakat sayye'

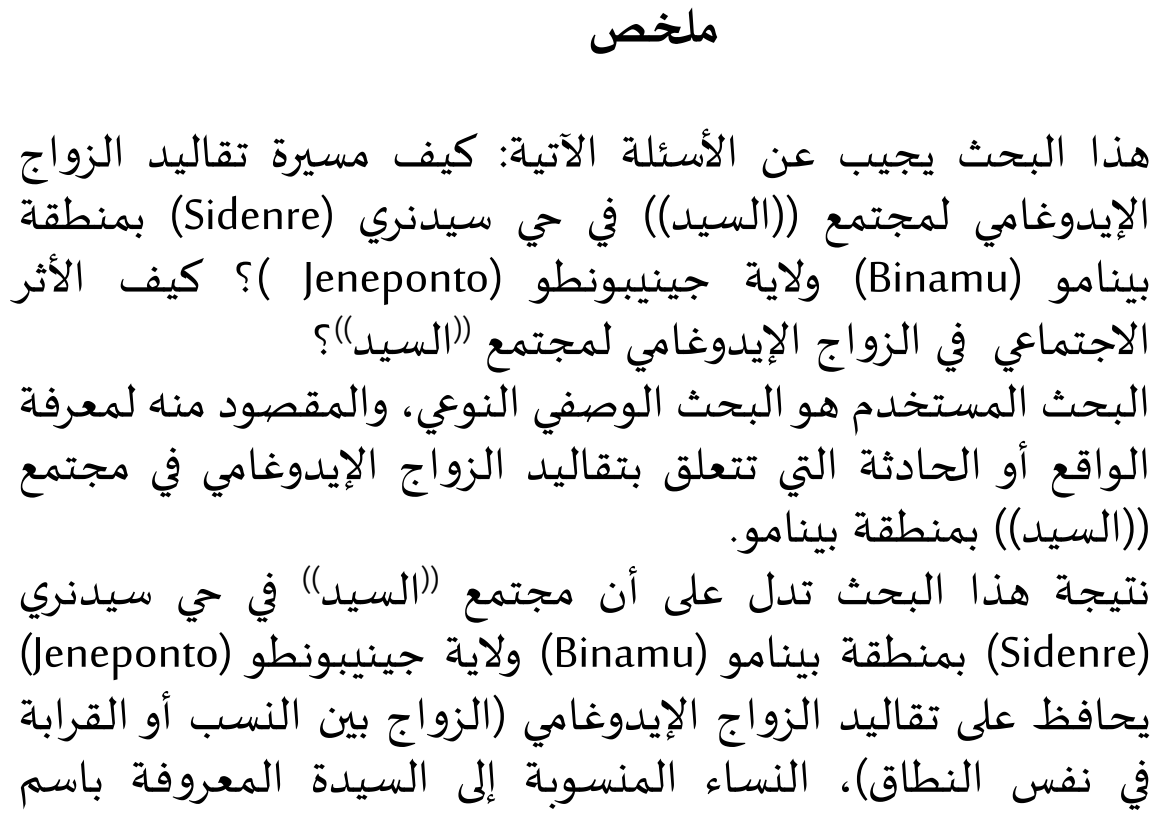




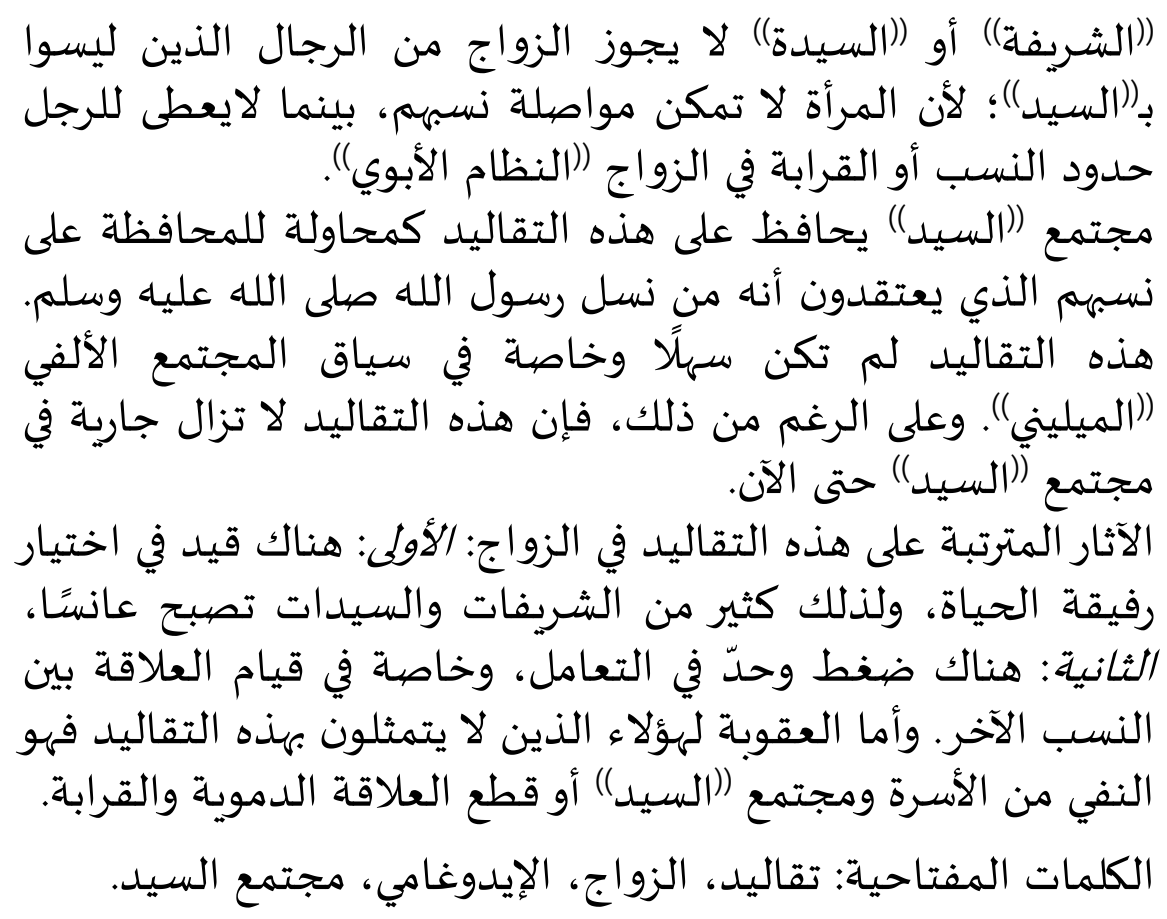

\section{A. Introduction}

The presence of the Arabian in Indonesia has been estimated since the $13^{\text {th }}$ century, namely since the fall of Baghdad Kingdom by Mongolian. Their presence in the archipelago as the Arabian merchant and an Islamic Proselytizer can be found in several regions in Indonesia, such as in South Sulawesi, including in Sidenre Village, Binamu District, Jeneponto Regency.

One of the uniqueness of this community is their efforts in maintaining clans or tribes through marriage which indicated that the relations with the outside world are very easy and wide open, which impact the consequences for inter-tribal marriages and countries. Thus, the effort of maintaining the tradition of community marriage, especially the marriage of Sayyid with sayyidah or syarifah is arduous. The type of its marriage (endogamy) is also found in Arabian community in several regions in Indonesia.

In defending their lineage, which is associated with the descendants of the Prophet Muhammad Saw, syarifah is prohibited to marry with other communities as the special requisite for women among sayyid community. However, the men had no no restrictions on marrying women outside of their community. To continue their lineage, the male name will be continued to their next offspring whereas syarifah reputed cannot continue their clan's name.

There were some interesting things on this marriage that the rituals of this tradition are Makassar tribal culture which showed the acculturation culture between 
Islam and Makassar tribe such as akkorontigi, mappatamma, doi pannai and many others.

In Arabian or Sayyid community in Sidenre Subdistrict, Binamu Subdistrict, Jenneponto Regency, they stil had coercive rules on this tradition to maintain the status of "sayyid". It revealed that syarifah or sayyidah is prohibited to marry with other community who are not sayyid. Eventhough, there some cases revealed that many syarifah violated the rules which means that they get sanctions from the Sayyid community.

Shils in his book Piotr Sztompka believed that tradition means everything that is channeled or passed down from the past to the present. ${ }^{1}$ Tradition is a comprehensive system, which consists any aspects and giving meaning to speech, ritual and various of many behaviors of humans in their daily life. ${ }^{2}$

Therefore, violating a tradition can give an impact; which can interfere the harmony or damage the order and stability of interpersonal community. Sayyidah who violate this tradition will get sanctions, especially social sanctions. Therefore, the author is interested in studying Endogamy Marriage in Sidenre Viilage of Binamu district in Jenneponto Regency.

\section{B. Research Method}

\section{Research Type}

This research is field research which means that the researcher does the observation directly. This research was namely qualitative descriptive that aimed at exploring the phenomenon about endogamy marriage

\section{Research Approach}

The researcher used some approaches below:

a. Historically Approach

Through historical approach, the researcher can find out the event related to phenomenon of endogamy marriage of Sayyed community at Binamu Subs district. $^{3}$

b. Religion Approach

All mankind actually has God as the creator of this universe. Through this method, this research is demanded to show the tradition comparison before and after Islam by seeing the religion aspect to be kept and spread out based on Islamic Religion. ${ }^{4}$

${ }^{1}$ Piotr Sztompka, Sosiologi Perubahan Sosial, IV (Jakarta: Prenada, 2011), h. 70.

${ }^{2}$ Wasid, Menafsirkan Tradisi \& Modernitas: Ide-Ide Pembaharuan Islam (Surabaya: Pustaka Idea, 2011), h. 30. 2010), h. 48

${ }^{3}$ Abuddin Nata, Metodologi Studi Islam, XVII (Jakarta: Rajagrafindo Persada (Rajawali Pers),

${ }^{4}$ Dudung Abdurrahman, Metodologi Penelitian Sejarah Islam (Yogyakarta: Ombak, 2011). 


\section{Data Source}

This research choose the data based on the skill and capability of the researcher in order to reveal the phenomenon objectively and choose the respondents based on some qualifications. It is required to fulfill research needs to show natural and factual data.

This research tried to explore about the phenomenon based on the information of respondents as the primary data who has knowledge and understanding of endogamy marriage in Binamu District.

The researcher used some steps as follow:

a. Primary Data

In field research, primary data was the main data which taken from informants such as traditional leaders and public figure.

b. Secondary Data

It is known as supporting data and taken through literary review such as books or documents to get the valid data.

\section{Data Collection Procedures}

a. Observation Method

Observation is known by using five senses in observing the research object, ${ }^{5}$ which means that the researcher conducts the observation directly in that place.

b. Interview

Interview technique was structurally due to the researcher prepared some problems and questions toward the respondents in order to get the valid data about the tradition of endogamy marriage of Sayyed Community in Binamu.

c. Field Notes directly.

Field notes aimed at collecting the data from the data source and informant

d. Documentation

The researched used documentation method as the data source to examine, transcribe, and guess through content analysis which means by concluding some aspect in order to gain its characteristic message.

\section{Data Analysis Technique}

The researcher tried to analyze the finding based on some data collection technique as follow:

a. Inductive method, means the element of research is from general to special.

b. Deductive method, means trying to analyze the problem generally to special.

c. Comparative method, means trying to compare some expert arguments in order to draw the final conclusion.

Some steps are applied in this research, they are: data reduction, data classification, presenting the data, and validity data.

${ }^{5}$ Suharsimi Arikunto, Prosedur Penelitian : Suatu Pendekatan Praktik (Jakarta: Rineka Cipta, 2002), h. 133. 


\section{Result and Discussion}

\section{The Procession of Endogamy Wedding among Sayyid Community in Sidenre Village, Binamu Subdistrict of Jeneponto Regency}

Sayyid community in Sidenre village known as a community that still upholds the values of their ancestors, who claimed themselves as lineage of the Prophet Muhammad Saw. To keep their lineage, the community perpetuates concept of "family termination" if their daughter or syarifah marries with a man who is not a descendant of Sayyid. Because they believed that Sayyidah who is married with other men reputed to dropped the family rank.

Nowadays, maintaining this tradition can be complicated matter especially the selection of candidates and the marriage process also requires extra-work. The Findings showed that this ritual became quite arduous and spend lot of money.

There are some Endogamy marriage processions in Sanrobone Village, Jenneponto Regency is as follows:

a. Propose Marriage

Propose marriage means that the male party came to Syarifah residence with the intention of proposing marriang formally. This male delegation is led by an elder family or someone who has experience in processions. There are several important things that will be negotiated between the two parties in this procession, namely; doe 'balanja / doe' panaik (marriage expenditure) and sundrang (dowry).

1) Doe' Panaik (Marriage expenditure)

Doe' panaik or marriage expenditure is the amount of money given by the prospective bridegroom to the prospective bride. Panaik money is a symbol of appreciation and respect of male as the symbol of the bride's social status that the amount of money based on the agreement of both parties.

Generally, Doe' Panaik is given as much as possible and not burdensome for men. The findings revealed that, doe' panaik becomes a problem because it burdens men. This is in accordance with the aim of giving the good deed as a tribute and a symbol of the social strata of the bride and groom.

2) Sunrang (Dowry)

Sunrang means dowry. Unlike the doe panaik, Sunrang is fully determined by men, in the form of gems or white gold. Sayyid community refers to the dowry that Ali r.a. gave to Sitti Fatimah r.a. in the form of a jewel. Sunrang is a woman's right that must be fulfilled by the man who will marry her.

3) Erang-erang (Marriage Properties)

Erang-erang means delivery goods or property in marriage; it usually in the form of toiletries, make-up equipment and some traditional cakes. Erang-erang is symbolized as a gift presented by groom to bride. The both family attended to witness the delivery of the prospective bridegroom. The existence of erang-erang in this procession, colorizes marriage ritual royally.

b. Akburitta (determination of a good day and date)

Akburitta is about the notification about the day and date of marriage to the family. It concerns about the family lineage, religion and occupation which is done 
orally or in writing. It intended verbally to the closest family, while the written form for an invitation intended their relative and other family among their community.

c. Patamma (read through to the end of Al-Qur'an)

Patamma' is to finish reciting the Quran for the bride and groom. This procession is only done for prospective marriage who have not yet recited to the end of the Qur'an. Thus the Khatam al-quran event is a symbol that the bride and groom had already recited to the end of the Qur'an. Patamma' revealed that the ideal bride and groom are people who are already familiar with the Quran. Khatam al-quran means that they can recite Qur'an well.

In this event, the surah that is usually recited is started from surah ad-Duha till surah an-Nas and they continue reciting surah al-Fatihah and surah al-Baqarah verses 1 to 5 which is ended by the prayer of Khatam Al-Quran.

The patamma procession was carried out before the wedding ceremony and was held in the house of each prospective marriage which aimed to complete the recitation of the bride and groom's bride.

d. Akkorontigi (giving korontigi concoction as admiration to groom and bride)

Akkorontigi means the ceremony to spice up the leko 'korontigi concoction. Akkorontingi has philosophical values of enlighting the life journey of the bridegroom. Therefore, both prospective marriage asked their parent's and relatives' blessing in order that they can face the household in any condition and of what they desired and they also can build the family of mawaddah wa rahmah. who said that:

Akarontigi was held for three nights, based on messages from previous people

"Pasangi ri ana' cucunnu nasaba I kau into tena na sengkamma tumaraenga punna nia' into wattu baji' tallung banngi karontigi, amuntuli tongko tallumbanngi. Anngalleko je'ne rawa ri binangayya punna erokko ammuntuli nanu pabasa ri karontiginu"

Meaning: Tell your grandchildren that you are different from others. The good times three nights karontigi, and ammuntuli is also held for three nights. Get the water in the river if you want to do ammuntuli and let you wet on the night of karontiginu"

The message above means as a reminder of the traditions from the ancient in order to continue the tradition and it also become the instruction of determining "good time" in carrying out the tradition, especially in akkorontigi ritual.

Even though, it is mentioned that this tradition was carried out for three days, it seems that the present community in carrying out this tradition is usually only one day, depending on financial and time skills for those who carry out the akkorontigi tradition.

The Akkorontigi tradition is not only transmitted by society in Sidenre, but also by the Sayye community in Sidenre village. Even the Sayyid community in Sidenre has different procedures than others, especially in the process and rituals of akkorontigi. Therefore, that every religious activity carried out by the Sayye community will be interesting to watch by society.

The rituals of the akkorontigi tradition are as follows:

a) Naung Ri Je'neka (submerged into the water) 
In this ritual, both prospective marriage brings equipment to be used in the Akkorontigi tradition. The equipment is sprinkled with water. Then, the equipment is bringing to the elder who is appointed at the event (people who know the Sayyid custom) to bless the equipment. Sayyid community believed that this tradition originates from La'buakkang who named as Karaeng Pokki (who is believed as a crocodile incarnation without tails). The Sayyid community attributed the words of Karaeng Pokki from Karaeng (Jenneponto Noble) and Sayyid (descendants of the Prophet). Because in the past, no one dared to marry Karaeng's children except Sayyid descendants. Therefore, they are placed in the high position of social strata as Sayye Karaeng.

Based on the author's observation, this ritual is a session to show the existence of the nobility of prospective marriage, namely as the descendants of Karaeng as well as the descendants of Sayyid. The authors believed that this ritual is quite important for the Sayyid community to show the existence that this marriage is a marriage of highborn (noble lineage).

b) Appepe'pepe' (Playing with Fire)

This ritual is held at night before doing Akkorontigi. The relatives of a married family will be crowd round the fire then they spin and carry ula-ula ${ }^{6}$ accompanied by a Ganrang ${ }^{7}$. Moreover, this panggadakkang is under Campoli with Dg. Ngalle who was born from fire ${ }^{8}$.

Sayyid community performs the ritual as the manifestation that in the midst of their happiness (hunger for marriage), they also express the sense of happiness by remembering that they are from crocodile incarnation descent and born from fire. Sayyid community believed that it will be dangerous if they do not carry out the ritual; then they will get disaster such as marriage ceremony faced some obstacles.

This ritual showed that the Sayyid community in the Sidenre Village of Bunamu Subdistrict admitted that they also had patronage from the Makassar tribal nobility. e. Implementation of Marriage Agreement - Ijab Qabul

The ritual of carrying out the marriage contract beginning with the groom when he arrived at the bride' place would use a marrak boat. ${ }^{9}$ It is about 20 meters from the bride's house, the groom rides the marrak accompanied by an a'rate ${ }^{10}$ to the front of the bride's house and the groom were picked up to enter the woman's house. The material from marrak itself is from bamboo, which is from their ancient and it has philosophical values there was a person born from bamboo named Banri dg Manurung. This ritual is part of the marriage ceremony procession.

${ }^{6}$ Ula-ula means flag with human as the symbols.

${ }^{7}$ Ganrang is one of traditional instruments used in ceremony.

${ }^{8}$ Interview result of Mr. Ngewa, (Sidenre: $27^{\text {th }}$ of July 2017)

${ }^{9}$ Marrak is derived from Makassarese words which means the boat made from bamboo. This is specially intended to the bride from the groom.

${ }^{10} A$ 'rate or Rate is a song/ poems that contains prays to the bride. 
Finally, the marriage contract (Ijab Qabul) can be started which means that the groom performs the Ijab-Qabul (recitation of the promise) with the custodian who is usually appointed to her father or substitute custodian.

\section{The Social Impact of the Sayyid Community Endogamy Marriage}

\section{Tradition}

Sayyid community in Sidenre village occupies a high class community, they are respected because they are considered as descendants of the Prophet Muhammad Saw.

Discussing about Endogamy tradition has faced complicated problem among society. The people who are not Sayyid assumed that this tradition is very excessive. This tradition has built a barrier between Arabian and non-Arabian ${ }^{11}$ Some people who has contradicted to this marriage tradition, believed that this tradition is actually not from Islamic teaching which can be seen on the hadith that advocates people to marry with other community.

There are two impacts of the marriage endogamy tradition among sayyid community as follows:

1. There is a limitation of choosing a mate. So that many syarifah become spinster/unmarried.

2. There is a limitation of interacting to the lower class among society in order to avoid the personal relation.

This cultural system is actually from thoughts, ideas, concepts, themes of thinking and beliefs which was commonly called as customs. These customs itself contained "cultural value system", "norm system" which can specifically be specified in various norms based on the regulation among their community. The function of a cultural system is actually to organize and strengthen human actions and behavior.

Even though the sayyid endogamy marriage tradition has a negative impact especially for syarifah, but it showed that the Sayyid community has maintained their traditions despite sacrificing the status of the syarifah. (who chose the life became spenster).

Regarding to the negative effects, there is also a positive impact on the Sayyid Endogamy marriages tradition, as follow:

1. As a site event for keeping the relations among Sayyid Community who live in other place which means that this tradition can unite them all in one place.

2. As an education, because this tradition teaches and tells them that customs must be remain guarded and preserved.

Members of the Sayyid family who violate endogamy marriages, they will be given sanctions. Sayye's family has chosen to isolate them or expel them from the family environment. There are also syarifah who violate, are considered no longer family; they are considered dead. Some even committed fatal actions to eliminate the lives of those who violated the tradition. Because they disobeyed the rules and broke the lineage of the descendants of the Prophet Muhammad. Nowadays, this punishment is not existing anymore.

${ }^{11}$ Jafar Shadiq, interviewed on $20^{\text {th }}$ of July 2017 at Sidenre. 
However, not all of Sayyid's family carries on this tradition because there some Sayyid 'family who let syarifah or sayyidah marry with non-sayyid. In this case they did not trust the custom or tradition. This family is more flexible than other sayyid families. Eventhough, this family will receive a social impact from the Sayyid community who still retain the endogamy marital tradition and being excluded from the Sayyid community.

\section{Sanctions for Disobeying Endogamy Marriage Traditions}

One of Sayye's community beliefs that the birth of endogamy marriages term is from the the statement below: "All of Adam's descendants were cut off in the next day, except the Prophet Muhammad's Nasab. Nasab will be cut off if the grandchildren of the Prophet Muhammad Saw himself decided ". Sayyid community understands that nasab is cut off when the syarifah marries someone who is not sayye. Therefore, they consider syarifah's marriage with non-sayye to be considered unlawful in the life of the Sayye community. ${ }^{12}$

The implementation of the kafa'ah carried out by the alawiyin families was based on the actions of the Prophet, which was exemplified in marrying off his daughter Fatimah with Ali bin Abi Talib. This also underlies the Sayye's family to look after their daughter to be exemplified in marrying her daughter to keep marrying men who has the same with them till now.

Kufu or kafa'ah has meaning equivalence. It is namely the equivalent of prospective husbands and prospective wives who will marry and foster households. The term kufu appears in several hadiths, in the form of advice from the Prophet to immediately marry or marry a Muslim woman who has found a suitable future husband. Among these hadiths, the best is the history of Tirmidhi, which has been exhorted by Al-albani.

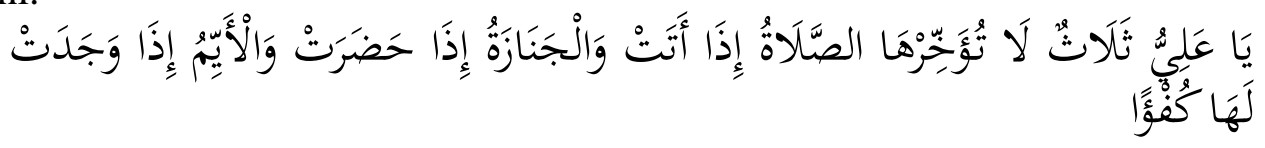

Meaning:

"O Ali, there are three cases that you should not delay; prayer when the time has come, the corpse when it is ready for burial, and the woman if she has found her soul mate is equal / equal (HR. Tirmidhi; Hasan Hadith).

This hadits describe that sekufu is necessary. It is not a condition and pillar of marriage but it can be one of qualification of the marriage preservation.

The meaning of kafa'ah or kufu 'in marriage, according to the term Islamic law, namely, the balance and harmony between the prospective husband and wife so that each candidate does not feel heavy to get married. ${ }^{13}$

\footnotetext{
${ }^{12}$ Rezky Mulia Indah, 'Kedudukan Anak Perempuan Keturunan Sayyid Yang Menikah Dengan Laki-Laki Yang Bukan Keturunan Sayyid Terhadap Harta Warisan Orang Tua Di Desa Cikoang Kabupaten Takalar' (Universitas Hasanuddin, 2017), h. 47.

${ }^{13}$ Hussan Duramae, PERKAWINAN SEKUFU DALAM PERSPEKTIF HUKUM ISLAM (Studi Kasus di Daerah Napradu Provinsi Pattani ThailandSelatan), Jurnal Bilancia, Vol. 12 No. 1, Januari-Juni 2018), h. 81.
} 
If there has been a marriage between the syarifah and the man who is not sayye, then the offspring of them is not sayyid anymore. That is because the child follows his father's line (patriarchal system), the implication of special virtue and glory given by Allah Swt which the offspring cannot be carried by the children of the descendants of a syarifah who married men who were not sayye '. ${ }^{14}$

The Traditional marriage must be comprehended as a form of marriage based on customary rules and customs prevailing in the local community. These rules are a manifestation of culture which consists values and norms. These values and norms are reflected in the form of other generations as cultural heritage in order that they can interact among community.

The traditional marriage is a marriage ceremony that is formed, organized and implemented by the rules which apply in every local customary community environment. Customary law itself by Soerojo Wignjodipoero is referred as a complex norm that develops and encompasses the rules of human behavior in daily life. Most of the rules are written, always obeyed and respected by the people because they have legal consequences (sanctions). ${ }^{15}$

In the Sidenre Village, which still leads to the values of their ancestors, where the community claims that they are descendants of Sayyid, there is a concept of terminating the family if their daughter marries men who are not Sayye's descendants.

In the Sidenre village, there are unwritten rules understood by all residents in the village, it is namely the rules of marriage among Sayyid community. This rule has become a 'hereditary' culture in determining their child's soul mate to maintain the integrity of their identity in order that Sayyid women descent or known as syarifah may not marry men who come from outside of their community. Their offspring's blood is considered to be no longer pure or has been contaminated with non-sayyid blood. ${ }^{16}$

This problem can be found in many places with different term among them. This is never regulated in positive law except in customary law. This problem like this concern family law and one of its scope includes the relationship between parents and children, and this is very closely related to inheritance law that is related to heirs.

Based on Mr. Ngewa, who understands Sayye's customs better: Everyone has the right to marry anyone and it applies among Sayye community and they must accept the consequences in the sense of accepting all sanctions given by the family and hereafter. ${ }^{17}$

${ }^{14}$ Alwi Idrus Almasyhur, Sekitar Kafa'ah Syarifah Dan Dasar Hukum Syari'ahnya, I (Jakarta: Yayasan Almustarsyidin, 2002), h. 45.

${ }^{15}$ Soerojo Wignjodipoero, Pengantar Asas-Asas Hukum Adat (Jakarta: Gunung Agung, 1984).

${ }^{16}$ Fajar.co.id, 'Nikahi Pria Di Luar Komunitas Siap Dibuang Dari Keluarga', 2017, p. FAJAR <www.fajar.co.id/read-20120328003136-nikahi-pria-di-luar-komunitas-siap-dibuang-darikeluarga>.

${ }^{17} \mathrm{Mr}$. Ngewa was interviewed about Sayyed Marriage tradition in Sidenre of Jeneponton Regency on $27^{\text {th }}$ of July 2018 
Based on the results of the interview above, it can be concluded that, they may marry with anyone that he wants. But it does not mean free from the applicable sanctions. There are sanctions received for those who violate customary provisions.

In marriage with Sayye, they have some rules if women from the Sayyid descendants are married with ordinary men. Therefore, sanctions in the form of exile from the family of women, there ar also those who sever their relationships, most fatal sanctions are killing them, eventhough this latter sanction is certainly no longer found today.

Based on Tuang Ngampi:

There was a misunderstanding in the wedding where the men from Sayye's descendants 'and the women from ordinary circles, at that time before they do the Ijab Qabul. The women's side the problem was the dowry of that sayye' customs used ringgit as the dowry of marriage. ${ }^{18}$ Because of a misunderstanding, it was debated among the parties, in this debate there were those carrying sharp weapons such as machetes and machetes and muttering each other. This debate occurred because maintaining each other's customs on the other hand also guarded the Siri'. After the debate session, the two sides finally agreed to negotiate and finally the men gave a piece of land to the women but not as dowry but only as usual. ${ }^{19}$

This proves that Sayyid's custom of marriage is bound by rules. Sayyid community always keep siri' among them..$^{20}$ Because, if they want to build a respectable and perfect living society, it is known to be an unwritten expression in society, namely siri 'na pace (sipassiriki na sipappaccei).

Sipassiriki na sipappacce $i$ which means keeping each other's pace together, and they uphold the same pace of sirina law. He naturally tries to distance himself from offending others and is ready to help (provide assistance) if necessary. The spirit of Sipassiriki $\mathrm{Na}$ Sipappacei is applied in the community especially in the family environment.

B. F. Mattes, for example, translating the term siri' with shame, his sense of honor is offended. C. H. Salam Basjah, a member of three notions to the concept of siri', is embarrassed, a driving force to destroy anyone who has offended someone's sense of honor, or the driving force to work or try as much as possible. Natzir Said stated that siri 'is a moral feeling to kill those who violate adat, especially in matters of marital relations. ${ }^{21}$

Siri 'is a life view or cultural value that is considered very high and valuable as a behavior in the life of the Makassar tribe. Various parties interpret this concept as self-esteem, honor, dignity, soul, and shame.

\footnotetext{
${ }^{18}$ Ringgit means white gold or diamond as dowry to the bride.

${ }^{19} \mathrm{Mr}$. Ngampi, was interviewed on $27^{\text {th }}$ of July 2017 in Sidenre disctrict of Binamu of Jeneponto Regency.

${ }^{20}$ Siri' means humble or self pride to maintain the culture.

${ }^{21}$ Koenntjaningrat, Beberapa Pokok Antropologi Sosial (Jakarta: Dian Rakyat, 1985), h. 274.
} 
There is their belief that when syarifah marries men who are not from Sayyid the sanctions are not only obtained in the world in the form of social sanctions from the Sayye' community but also sanctions in the hereafter. follows:

This is in accordance with the results of the interview with Tuang Ngewa, as

Put in Hell but different from ordinary torture, they have their own special place for the Sayye 'community, if the others torture with burning fire but it's different from Sayye' who is tortured with water but the heat is even hotter than fire. ${ }^{22}$

Based on the statement, it can be stated that the people of Sayyid believe that the impact of violating these rules is quite hard, even as some people say that Sayye will get torture in the hereafter. They believe that in the hereafter, they get a different place, because they consider themselves descended from the Prophet Muhammad Saw.

\section{Conclusion}

The conclusions of this article are as follows:

1. Sayye's wedding tradition in the Sidenre of Bnamu Subdistrict, Jenneponto District is different from marriage generally. It is especially in determining the bride and groom which have the same requirements / equivalent or have the same clans, Sayyid. The interesting topic about this tradition is that the rituals along with this marriage tradition are the tribal traditions of Makassar and some are acculturations of the Islamic culture and tribal culture of Makassar in order that the rituals shows that the Sayyid people in Sidenre Village admitted that they also have nasab/lineage from offspring Makassar nobility.

2. The impact of the Sayyid community endogamy marriage tradition is that many Syarifah or Sayyidah become spinsters. Moreover, in the context of society, the relationship between place, region and even the state is getting closer, which brings consequences for inter-tribal marriages, even between countries is no stranger. Unfortunately, keeping this marriage is not an easy matter.

3. In marriage Sayye, they have rules if women of Sayye' descent marry ordinary men, they get sanctions in the form of exile from the family and they community break up blood relations with them. The most fatal sanction is killing the women. This latter sanction is not found today because it will disobey criminal law. Besides sanctions in the world, the Sayye 'community also believes that Sharifah is married to a man who is not Sayye; then the sanctions are not only obtained in the world but they will get in hereafter.

\footnotetext{
${ }^{22} \mathrm{Mr}$. Ngewa, who understand sayyed tradition, interviewed on $27^{\text {th }}$ of July 2017 at Binamu Subsdistrict of Jeneponto Regency.
} 


\section{BIBLIOGRAPHY}

Abdurrahman, Dudung, Metodologi Penelitian Sejarah Islam (Yogyakarta: Ombak, 2011)

Almasyhur, Alwi Idrus, Sekitar Kafa'ah Syarifah Dan Dasar Hukum Syari'ahnya, I (Jakarta: Yayasan Almustarsyidin, 2002)

Arikunto, Suharsimi, Prosedur Penelitian : Suatu Pendekatan Praktik (Jakarta: Rineka Cipta, 2002)

Duramae, Hussan. Perkawinan Sekufu Dalam Perspektif Hukum Islam (Studi Kasus di Daerah Napradu Provinsi Pattani ThailandSelatan), Jurnal Bilancia, Vol. 12 No. 1, Januari-Juni 2018)

Fajar.co.id, 'Nikahi Pria Di Luar Komunitas Siap Dibuang Dari Keluarga', 2017, p. FAJAR <www.fajar.co.id/read-20120328003136-nikahi-pria-di-luarkomunitas-siap-dibuang-darikeluarga $>$

Indah, Rezky Mulia, 'Kedudukan Anak Perempuan Keturunan Sayyid Yang Menikah Dengan Laki-Laki Yang Bukan Keturunan Sayyid Terhadap Harta Warisan Orang Tua Di Desa Cikoang Kabupaten Takalar' (Universitas Hasanuddin, 2017)

Koenntjaningrat, Beberapa Pokok Antropologi Sosial (Jakarta: Dian Rakyat, 1985)

Nata, Abuddin, Metodologi Studi Islam, XVII (Jakarta: Rajagrafindo Persada (Rajawali Pers), 2010)

Sztompka, Piotr, Sosiologi Perubahan Sosial, IV (Jakarta: Prenada, 2011)

Wasid, Menafsirkan Tradisi \& Modernitas: Ide-Ide Pembaharuan Islam (Surabaya: Pustaka Idea, 2011)

Wignjodipoero, Soerojo, 'Pengantar Asas-Asas Hukum Adat' (Jakarta: Gunung Agung, 1984) 


\section{Guidelines}

\section{Submission of Article}

urnal Adabiyah welcomes the articles submission with the main themes on Humanities and Islamic Studies with the emphasis on interdisciplinary and intertextuality approach. Adabiyah is thematicly published twice in a year. ie the theme of the humanities in June and the Islamic Study in December.

Themes related to Islamic Studies are textual studies, scriptural traditions, Islamic law, and theology; and those related to Humanities are language, literature, history, and culture. This scholarly journal Guarantees that the editor decision based on the peer review results will not exceed 30 days from the paper submission date.

Authors are invited to read our archives; to find the relevant topics for the journal, and to submit complete unpublished scientific researches, which are not under review in any other conferences or academic journal.

\section{PUBLICATION ETHIC}

Publication Ethic and Malpractice Statement

Jurnal Adabiyah is a peer-reviewed journal, published twice a year by the Faculty of Adab and Humaniora, Alauddin State Islamic University of Makassar Indonesia. It is available online as open access sources as well as in print. This statement clarifies ethical behaviour of all parties involved in the act of publishing an article in this journal, including the author, the editor-in-chief, the Editorial Board, the reviewers, and the publisher. This statement is based on COPE's Best Practice Guidelines for Journal Editors.

Ethical Guideline for Journal Publication

The publication of an article in Jurnal Adabiyah, is an essential building block in the development of a coherent and respected network of knowledge. It is a direct reflection of the quality of the work of the authors and the institutions that support them. Peer-reviewed articles support and embody the scientific methods. It is therefore important to agree upon standards of expected ethical behavior for all parties involved in the act of publishing: the author, the editor, the reviewer, the publisher, and the society. As the publisher of Jurnal Adabiyah, the Faculty of Adab and Humaniora takes its duties of guardianship over all stages of publishing seriously and it recognizes its ethical and other responsibilities. The Faculty of Adab and Humaniora committed to ensuring that advertising, reprint or other commercial revenue has no impact or influence on editorial decisions.

\section{Publication Decisions}

The editors of Jurnal Adabiyah is responsible for deciding which articles submitted to the journal should be published. The validation of the work in question and its importance to researchers and readers must always drive such decisions. The editors may be guided by the policies of the journal's editorial board and constrained by such legal requirements as shall then be in force regarding libel, copyright infringement, and plagiarism. The editors may confer with other editors or reviewers in making their decisions.

\section{Plagiarism Screening}

It is basically author's duty to only submit a manuscript that is free from plagiarism and academically malpractices. The editor, however, will check all submitted papers through Turnitin.

\section{Fair Play}

An editor at any time evaluates manuscripts for their intellectual content without regard to race, gender, sexual orientation, religious belief, ethnic origin, citizenship, or political philosophy of the authors. 


\section{Confidentiality}

The editors and any editorial staff must not disclose any information about a submitted manuscript to anyone other than the corresponding author, reviewers, potential reviewers, other editorial advisers, and the publisher, as appropriate.

\section{Disclosure and Conflicts of Interest}

Unpublished materials disclosed in a submitted manuscript must not be used in editors' own research without the express written consent of the author.

\section{DUTIES OF AUTHORS}

\section{Reporting Standards}

Authors of reports of original research should present an accurate account of the work performed as well as an objective discussion of its significance. Underlying data should be represented accurately in the paper. A paper should contain sufficient detail and references to permit others to replicate the work. Fraudulent or knowingly inaccurate statements constitute unethical behaviour and are unacceptable.

\section{Originality and Plagiarism}

The authors should ensure that they have written entirely original works, and if the authors have used the work and/or words of others that this has been appropriately cited or quoted.

\section{Multiple, Redundant, or Concurrent Publication}

An author should not in general publish manuscripts describing essentially the same research in more than one journal or primary publication. Submitting the same manuscript to more than one journal concurrently constitutes unethical publishing behaviour and is unacceptable.

\section{Acknowledgement of Sources}

Proper acknowledgment of the work of others must always be given. Authors should cite publications that have been influential in determining the nature of the reported work.

\section{Authorship of the Paper}

Authorship should be limited to those who have made a significant contribution to the conception, design, execution, or interpretation of the reported research. All those who have made significant contributions should be listed as co-authors. Where there are others who have participated in certain substantive aspects of the research project, they should be acknowledged or listed as contributors. The corresponding author should ensure that all appropriate co-authors and no inappropriate co-authors are included on the paper, and that all co-authors have seen and approved the final version of the paper and have agreed to its submission for publication.

\section{Disclosure and Conflicts of Interest}

All authors should disclose in their manuscript any financial or other substantive conflict of interest that might be construed to influence the results or interpretation of their manuscript. All sources of financial support for the project should be disclosed.

\section{Fundamental errors in Published Works}

When an author discovers a significant error or inaccuracy in his/her own published work, it is the author's obligation to promptly notify the journal editor or publisher and cooperate with the editor to retract or correct the paper.

\section{PLAGIARISMI}

It is basically author's duty to only submit a manuscript that is free from plagiarism and academically malpractices. The editor, however, will check all submitted papers through Turnitin. 


\section{AUTHOR GUIDELINES}

\section{Guidelines for online submission:}

1. Author should first register as Author to the website of Jurnal Adabiyah. Click the menu "register" to register as an author.

2. Once after the author is registered, please login to the website of Jurnal Adabiyah and submit the article through online submission (with the stat us of active submissions).

3. The article should follow the standard template of Jurnal Adabiyah provided in the website.

4. The citation and bibliography should follow the Turabian citation style.

5. Author is restricted not to send his/her article to another journal before having confirmation from the editorial team (approximately 4 weeks right after the article submitted).

6. Author should follow editorial decisions and recommendations related to the article completion. All reviews and assessements will be informed through online submission.

Article submitted to Jurnal Adabiyah editorial board must follow these guidelines:

1. Article should be based on the scientific research in the field humanities and Islamic studies;

2. Article must be an original work and has not been previously published;

3. Article should be written in Arabic or English languages;

4. Article must be typed in one-half spaced on A4-paper size;

5. Article's length is about $6,000-10,000$ words;

6. All submission must include a 150-250 word abstract;

7. Abstract should be written in 3 languages; Arabic, English, and Bahasa;

8. Full name(s) of the author(s) must be stated, along with his/her/their institution and complete address;

9. All submission should be in OpenOffice, Microsoft Word, RTF, or WordPerfect document file format;

10. Bibliographical reference must be noted in footnote and bibliography according to Jurnal Adabiyah style. In addition, it is suggested for author(s) to use reference manager tools such as 30 MENDELEY or 2 otero

When a source is cited for the first time, full information is provided: full name(s) of author(s), title of the source in italic, place of publication, publishing company, date of publication, and the precise page that is cited. For the following citations of the same source, list the author's last name, two or three words of the title, and the specific page number(s). The word ibid., op.cit., and loc.cit. are may not be used any more.

\section{Example in footnotes:}

${ }^{1}$ Mircea Eliade (ed.), The Encyclopedia of Religion, vol. 8 (New York: Simon and Schuster, 1995), h. 18.

${ }^{2}$ Norman Daniel, Islam and the West (Oxford: One World Publications, 1991), h. 190.

${ }^{3}$ Syeikh Ja'far Subhānī, Mafăhim Al-Qur'ān (Beirut: Mu'assasah Al-Tarikh Al-'Arabī, 2010)., Juz 5, h. 231. 
${ }^{4}$ Syeikh Ja'far Subhānī, Mafăhim Al-Qur'ān, h. 8-9.

\section{Example in bibliography:}

Subhānī, Syeikh Ja'far. Mafāhim Al-Qur'ān. Beirut: Mu'assasah Al-Tarikh Al-'Arabī, 2010.

Eliade, Mircea (ed.). The Encyclopedia of Religion, vol. 8. New York: Simon and Schuster, 1995.

Daniel, Norman. Islam and the West. Oxford: One World Publications, 1991.

Shihab, Muhammad Quraish. Sunnah-Syiah Bergandengan Tangan: Mungkinkah? Kajian Atas Konsep Ajaran Dan Pemikiran. Cet. III. Jakarta: Lentera Hati, 2007.

Detail informations of the footnotes:

1. Holy book

Al-Qur'ân, Al-Baqarah/2: 185.

Perjanjian Baru, Mrk. 2: 18.

2. Qur'anic translation

${ }^{1}$ Departemen Agama RI, al-Qur'an dan Terjemahannya (Jakarta: Darus Sunnah, 2005), h. 55.

3. Book

${ }^{1}$ Muḥammad 'Ajjaj al-Khațib, Ușl al-Hadith: 'Ulumuh wa Mușțalaḥuh (Beirut: Dâr al-Fikr, 1989), h. 57.

4. Translation Books

${ }^{1}$ Toshihiko Izutsu, Relasi Tuhan dan Manusia: Pendekatan Semantik terhadap al-Qur'an, terj. Agus Fahri Husein dkk (Yogyakarta: Tiara Wacana, 2003), h. 14.

5. Voluminous book

${ }^{1}$ Muḥammad al-Ṭâhir b. 'Ashur, al-Tạnn̄̄r wa al-Tanwīr, Vol. 25 (Tunisia: Dâr al-Suhûn, 2009), h. 76.

${ }^{1}$ Muḥammad b. Ismā‘īl al-Bukharī, al-Jami` al-Ṣahịḥ, Vol. 2 (Beirut: Dar al-Kutub al-‘Ilmìyah, 1999), h. 77.

6. Article in book

${ }^{1}$ Sahiron Syamsuddin, "Metode Intratekstualitas Muhammad Shahrur dalam Penafsiran al-Qur'an" dalam Abdul Mustaqim dan Sahiron Syamsuddin (eds.), Studi al-Qur'an Kontemporer: Wacana Baru Berbagai Metodologi Tafsir (Yogyakarta: Tiara Wacana, 2002), h. 139.

7. Article in encyclopaedia

${ }^{1}$ M. Th. Houtsma, "Kufr” dalam A. J. Wensinck, at al. (ed.), First Encyclopaedia of Islam, Vol. 6 (Leiden: E.J. Brill, 1987), h. 244.

8. Article in journal

${ }^{1}$ Muhammad Adlin Sila, "The Festivity of Maulid Nabi in Cikoang, South Sulawesi: Between Remembering and Exaggerating the Spirit of Prophet", Studia Islamika 8, no. 3 (2001): h. 9.

9. Article in mass media

${ }^{1}$ Masdar F. Mas'udi, "Hubungan Agama dan Negara", Kompas, 7 Agustus 2002. 
10. Article in Internet

${ }^{1}$ Muhammad Shahrūr, "Reading the Religious Teks: a New Approach" dalam http://www.shahrour.org/25 Februari 2010/diakses 5 Juni 2010.

11. Thesis or dissertation

${ }^{1}$ Syahruddin Usman, "KinerjaGuru Penddikan Agama Islam pada SMAN dan SMKN Kota Makassar”, Disertasi (Makassar: PPs UIN Alauddin, 2010), h. 200.

\section{COPYRIGHT NOTICE}

Authors who publish with this journal agree to the following terms:

1) Authors retain copyright and grant the journal right of first publication with the work simultaneously licensed under a Creative Commons Attribution License that allows others to share the work with an acknowledgement of the work's authorship and initial publication in this journal.

2) Authors are able to enter into separate, additional contractual arrangements for the non-exclusive distribution of the journal's published version of the work (e.g., post it to an institutional repository or publish it in a book), with an acknowledgement of its initial publication in this journal.

3)Authors are permitted and encouraged to post their work online (e.g., in institutional repositories or on their website) prior to and during the submission process, as it can lead to productive exchanges, as well as earlier and greater citation of published work (See The Effect of Open Access). 